
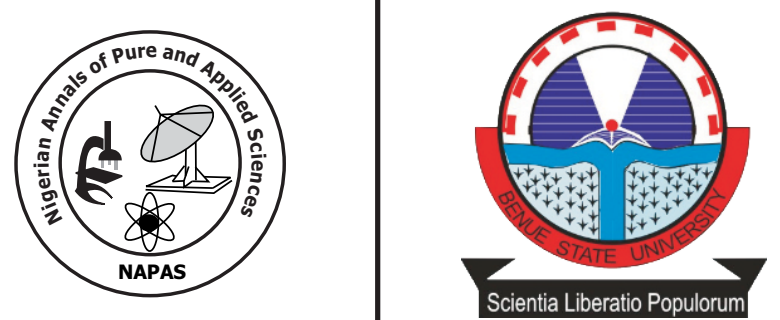

\title{
Studies on influence of human activities on the species diversity of Odonata in parts of Lagos metropolis
}

\section{Abstract}

\section{${ }^{1}$ Kemabonta, K. A., ${ }^{2}$ Adu, B. W., ${ }^{1}$ Akanni, N., ${ }^{1}$ Olajide, J.P and ${ }^{1}$ Uche-Dike R}

${ }^{1,}$ Department of Zoology, University of Lagos, Nigeria

${ }^{2}$ Department of Biology,

Federal University of Technology, Akure. Ondo State

*Correspondence author: kkemabonta@unilag.edu.ng

This study was conducted to determine dragonfly species diversity in a fish pond in Igbaga, Ikorodu $\left(6.6671^{\circ} \mathrm{N}\right.$ and $\left.3.5983^{\circ} \mathrm{E}\right)$ and a large expanse of farm land in Ipaja $\left(6.6044^{\circ} \mathrm{N}\right.$ and $\left.3.2660^{\circ} \mathrm{E}\right)$, southwestern Nigeria from January, 2016 to July, 2016 to as well as the effect of anthropogenic activities on the dragonflies at both sites. A total of 1002 dragonflies were collected belonging to 20 species, 15 genera, and two families (Libellulidae and Aesnidae), were found at the two locations. The most dominant species in Site 1 (Ikorodu fish farm) was Chalcostephia flavifrons (36\%) followed by Palpopleura lucia (15\%) and the least were Palpopleura albifrons, Gynacantha nigeriensis, Diplacodes lefebvrii and Trithemis grouti which were one percent of the total numbers sampled. On the other hand, the most dominant species in Site 2 (Agricultural Farm in Ipaja) was Pantala flavescens (92\%) and the least was Urothemis asignata (1\%). Similarity test using Soerensen's quotient revealed a strong dissimilarity in the community structures of the two areas surveyed. The fish pond had a more even distribution of the dragonflies $\left(\mathrm{e}^{\wedge} \mathrm{H} / \mathrm{S}=0.508\right)$ and a higher concentration $\left(\mathrm{H}^{\prime}=1.808\right)$ of dragonflies than Ipaja agricultural farm.

Key words: Odonata, Fish pond, Farmland, Diversity indices, Ikorodu, Ipaja 


\section{Introduction}

Dragonflies and Damselflies belong to the order Odonata which make up one of the most wellstudied and recognized insect groups (Kalkman et al., 2007). They are effective predators which feed on smaller insects which they catch airborne, on land or on vegetation (Duong, 2017, Collins et al., 2018). They are predators which are part of a larger food web as they are also preyed upon by a wide variety of organisms such as spiders, fishes, frogs, water bugs, and insectivorous birds. On the other hand, Dragonflies have many adaptations such as exceptional visual responses and truly agile flight enabling them to avoid predation (Corbet, 1999).Some genera and species are widespread while others are highly localized in their distribution. Some families are restricted to cool streams or rivers, others to ponds or still clear waters, and some to marshy places (Berquieret al., 2016). The presence of dragonflies and damselflies has been taken as an indication of good ecosystem quality. Information on the species richness and diversity of Anisoptera across countries such as East Africa (Dijkstra \& Clausnitzer, 2014), South Africa (Clausnitzer, 2017), Zambia (Bernard and Daraż 2018), Arabian peninsula (Schneider, and Samraoui, 2015), United Kingdom (Sahlén, et al., 2004) and India have been well documented. The documentation of the species diversity of Anisoptera in Nigeria is limited (Aduet al., 2013, 2015, 2016; Kemabonta et al, 2016). Therefore this study is part of ongoing research on base-line study of Nigerian Odonates. The objective of the study is therefore to determine and compare the species diversity of dragonflies from a fish pond in Igbaga,Ikorodu, Lagos, and an agricultural land in Ipaja, Lagos. The information derived would be useful in determining the level of disturbance of the environment and as part of the base-line study of Nigerian Odonates.

\section{Materials and methods \\ Description of study sites}

The first study Site 1 was carried out in a fish pond in Igbaga, Ikorodu with coordinates $6.6671^{\circ} \mathrm{N}$ and $3.5983^{\circ} \mathrm{E}$ (Figure 1). The area is characterized by marshy vegetation typical of tropical wetland regions in Lagos close to water bodies. The city is located North East of Lagos State along the Lagos Lagoon. It was formerly a massive forest lying less than 10 kilometres north of the Atlantic Ocean. It is home to a diverse range of insect species as well as other fauna including invertebrates of the orders; Arachnida and Myriapoda. Vertebrates at the sampling site include monitor lizards, snakes, rats, squirrels, domestic fowls, skinks and frogs.

The second study Site 2, was at The Ministry of Communication, Ipaja, Lagos with coordinates $6.6044^{\circ} \mathrm{N}$ and $3.2660^{\circ} \mathrm{E}$. It is a large expanse of land approximately 500 acres used majorly for agricultural purposes. It possesses small ponds, tall grasses and a variety of flora. The site also boasts of animal life such as crabs, squirrels, a wide variety of bird species as well as insects.

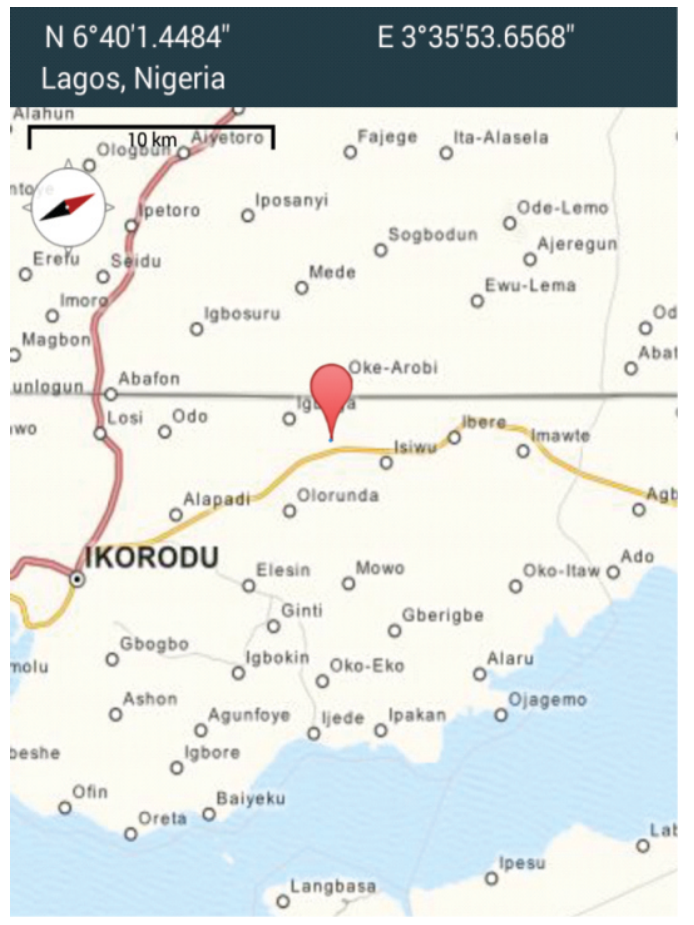

Figure 1: GPS showing the city of Ikorodu and the study area in Igbaga (Source: Google Maps)

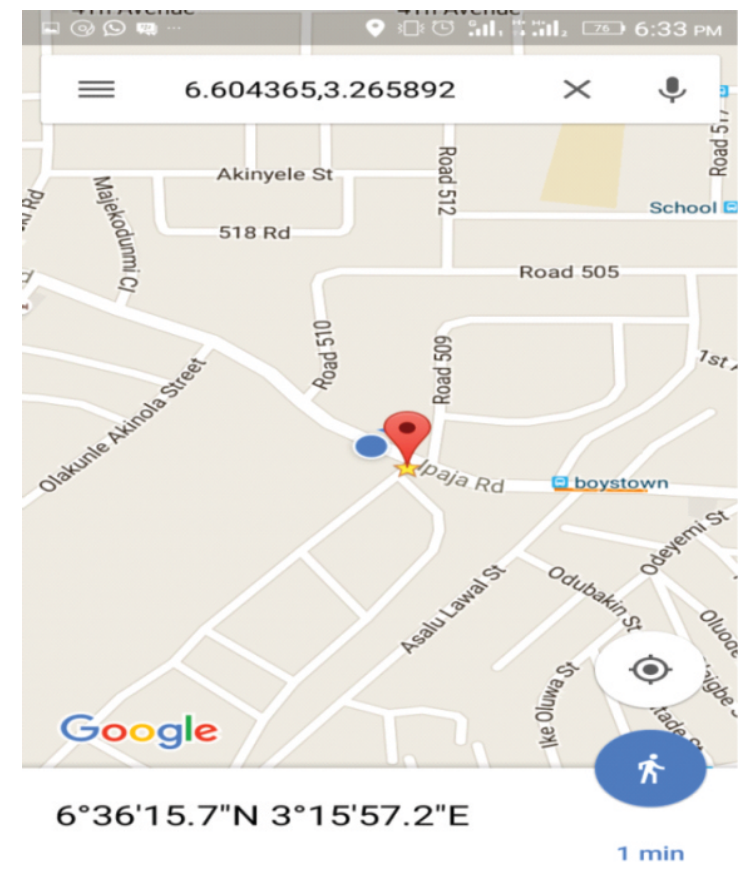

Figure 2: GPS showing the study site located at Ipaja, Lagos (Source: Google Maps) 


\section{Sample collection, preservation and identification}

The survey took place during the morning, afternoon and evening from $8 \mathrm{am}$ till $6 \mathrm{pm}$ at an average of 50 individuals per day. For this project, only adult odonates where collected to ensure easy and accurate identification of the specimens. Samples were collected with a sweep net that had a length of about $100 \mathrm{~cm}$ and an orifice measuring about $20 \mathrm{~cm}$ in diameter. The odonates were collected mid-flight or while they were perched on surrounding trees and substrate. They were carefully held by the wings to avoid injury and carefully placed in triangular envelopes which inhibited their movement. The triangular envelopes were numbered and labelled with pencils to avoid washing off when wet. Captured odonates were collected, counted, preserved and taken to the laboratory for identification and records of samples were kept. The odonates kept in the triangular envelopes were placed in a jar containing 70\% acetone for about 12 hours and then air dried; before being kept in an aerated transparent plastic. Camphor $\left(\mathrm{C}_{10} \mathrm{H}_{16} \mathrm{O}\right)$ was used to prevent entry and damage by other insects. The dragonflies were identified with appropriate keys (Vick, 1999; Dijkstra, \& Vick, 2004; Clausnitzer and Dijkstra, 2011) and cross-referenced with over 3,000 images of Afrotropical Odonata species on the World Wide Web (www.africandragonfly.net/global/results ).

\section{Data analysis}

The Palaeontological Statistics Software (PAST) for scientific data analysis was used to calculate the biodiversity indices and was used for the determination of species diversity at the sample site. The diversity indices were used to determine the richness of various dragonfly species at the study area.

\section{Similarity Test}

Similarity test on the community structure of the odonates sampled at the two study sites were carried out using Soerensen's Quotient.
Soerensen's Quotient for site $\mathrm{X}$ and $\mathrm{Y}$ is given as $2 J /(A+B)$, where: $A=$ number of species in site $X$, $\mathrm{B}=$ number of species in site $\mathrm{Y}, \mathrm{J}=$ number of species common to both. The value will be close to 1.0 for two compared sites that have common species and for dissimilar sites the value will be close to 0.0. Coefficient of similarity was estimated from the value obtained in the Soerensen's quotient analysis (Sarmisthaet al., 2009; Adu and Ogbogu, 2013). $<0.3=$ strongly dissimilar, 0.3-0.4= moderately dissimilar, 0.4$0.5=$ slightly dissimilar, $0.5-0.6=$ slightly similar, $0.6-0.7=$ moderately similar, $>0.7=$ strongly similar.

\section{Results}

A total number of 1002 individuals from two families (Libellulidae and Aesnidae), 15 genera and 20 species were found at the two locations. A total of 402 samples were collected from the fish pond at Ikoroducomprising 9 genera and 12 species (Table 1).Chalcostephia flavifrons had the highest number of samples caught with $36 \%$ of the composition of the samples caught and was found in every part of the study site 1 , while the least species caught were Palpopleura albifrons, Gynacantha nigeriensis, Diplacodes lefebvrii and Trithemis grouti at $1 \%$ of the total samples caught (Figure 3).The study site has a Shannon Weiner index of 1.808 and a Simpson's Dominance index of 0.783 . This study site also had an evenness value of $\mathrm{E}=0.508$ (Table 2 )

A total of 600 specimens were collected from study site 2 comprising one family Libellulidae genera (Figure 4). Pantala flavescens $(92 \%)$ had the highest number of samples recorded (Figure 4) and was found in every part of the study area while Tramea limbata $(1 \%)$ was the least species caught. The study site had a Shannon Weiner index of 0.391, a Simpson's Dominance index of 0.143 and an evenness value of $E=0.185$ (Table 2)

The two study sites, Ikorodu and Ipaja were found to have strongly dissimilar Odonata community structures $(<0.3)$ (Table 3 ). 
Table 1: Number of individuals per species of Odonata recorded in study Sites 1 and 2.

\begin{tabular}{|c|c|c|c|c|c|c|}
\hline $\mathbf{S} / \mathbf{N}$ & Family & Genus & Species & Common Name & $\begin{array}{l}\text { \# from } \\
\text { Site } 1\end{array}$ & $\begin{array}{l}\text { \# from } \\
\text { Site } 2\end{array}$ \\
\hline 1. & Aeshnidae & Gynacantha & $\begin{array}{l}\text { Gynacantha nigeriensis, } \\
\text { (Gambles, 1956) }\end{array}$ & $\begin{array}{l}\text { Yellow-legged } \\
\text { Duskhawker }\end{array}$ & 2 & 0 \\
\hline 2. & & Anax & $\begin{array}{l}\text { Anax imperator (Leach, } \\
1815)\end{array}$ & Blue Emperor & 8 & 0 \\
\hline 3. & Libellulidae & Palpopleura & $\begin{array}{l}\text { Palpopleura albifrons, } \\
\text { (Legrand, 1979) }\end{array}$ & $\begin{array}{l}\text { Pale-faced } \\
\text { widow }\end{array}$ & 6 & 0 \\
\hline 4. & 3 & & $\begin{array}{l}\text { Palpopleura portia, (Drury, } \\
1773 \text { ) }\end{array}$ & Portia Widow & 14 & 0 \\
\hline 5. & 4 & & $\begin{array}{l}\text { Palpopleura lucia (Drury, } \\
1773 \text { ) }\end{array}$ & Lucia Widow & 62 & 0 \\
\hline 6. & 5 & $\begin{array}{l}\text { Chalcostephi } \\
a\end{array}$ & $\begin{array}{l}\text { Chalcostephia flavifrons } \\
\text { (Kirby, 1889) }\end{array}$ & Yellowface & 144 & 0 \\
\hline 7. & 6 & Hadrothemis & $\begin{array}{l}\text { Hadrothemis camarensis } \\
\text { (Kirby, 1889) }\end{array}$ & $\begin{array}{l}\text { Saddled } \\
\text { Jungleskimmer }\end{array}$ & 88 & 0 \\
\hline 8. & 7 & Diplacodes & $\begin{array}{l}\text { Diplacodes lefebvrii. } \\
\text { (Burmeister, 1839) }\end{array}$ & Black Percher & 2 & 0 \\
\hline 9. & 8 & Acisoma & $\begin{array}{l}\text { Acisomatrifidum (Kirby, } \\
\text { 1889) }\end{array}$ & Pied pintail & 24 & 0 \\
\hline 10. & 9 & & $\begin{array}{l}\text { Acisomapanorpoides } \\
\text { (Rambur, 1842) }\end{array}$ & Grizzled Pintail & 42 & 0 \\
\hline 11. & $\begin{array}{l}1 \\
0\end{array}$ & Orthetrum & $\begin{array}{l}\text { Orthethrumtrinacria(Selys, } \\
1841 \text { ) }\end{array}$ & Long Skimmer & 8 & 0 \\
\hline 12. & & & $\begin{array}{l}\text { Orthetrumbrachiale (Palisot } \\
\text { de Beauvois, 1817) }\end{array}$ & Banded skimmer & 0 & 5 \\
\hline 13. & $\begin{array}{l}1 \\
1\end{array}$ & Trithemis & $\begin{array}{l}\text { Trithemisgrouti (Pinhey, } \\
\text { 1961) }\end{array}$ & Dark Dropwing & 0 & 2 \\
\hline 14. & 2 & Pantala & $\begin{array}{l}\text { Pantalaflavescens (Fabricius, } \\
\text { 1798) }\end{array}$ & $\begin{array}{l}\text { Wandering } \\
\text { Glider }\end{array}$ & 0 & 555 \\
\hline 15. & & Brachythemis & $\begin{array}{l}\text { Brachythemislacustris } \\
\text { (Kirby, 1889) }\end{array}$ & Red Groundling & 0 & 10 \\
\hline 16. & & Bradinopyga & $\begin{array}{l}\text { Bradinopygastrachani } \\
\text { (Kirby, 1900) }\end{array}$ & Red Rockdweller & 0 & 18 \\
\hline 17. & & Tramea & $\begin{array}{l}\text { Tramealimbata (Desjardins, } \\
\text { 1832) }\end{array}$ & $\begin{array}{l}\text { Ferruginous } \\
\text { Glider }\end{array}$ & 0 & 3 \\
\hline 18. & & Urothemis & $\begin{array}{l}\text { Urothemissignata (Rambur, } \\
1842 \text { ) }\end{array}$ & $\begin{array}{l}\text { Greater Crimson } \\
\text { Glider }\end{array}$ & 0 & 2 \\
\hline 19. & & & $\begin{array}{l}\text { Urothemisassignata (Selys, } \\
1872 \text { ) }\end{array}$ & Red basker & 0 & 3 \\
\hline 20. & & Olpogastra & $\begin{array}{l}\text { Olpogastralugubris (Karsch, } \\
1895 \text { ) }\end{array}$ & Bottletail & 0 & 4 \\
\hline
\end{tabular}

NB: Site 1 is Fish pond at Ikorodu

Site 2 is Agricultural farm at Ipaja, Lagos 


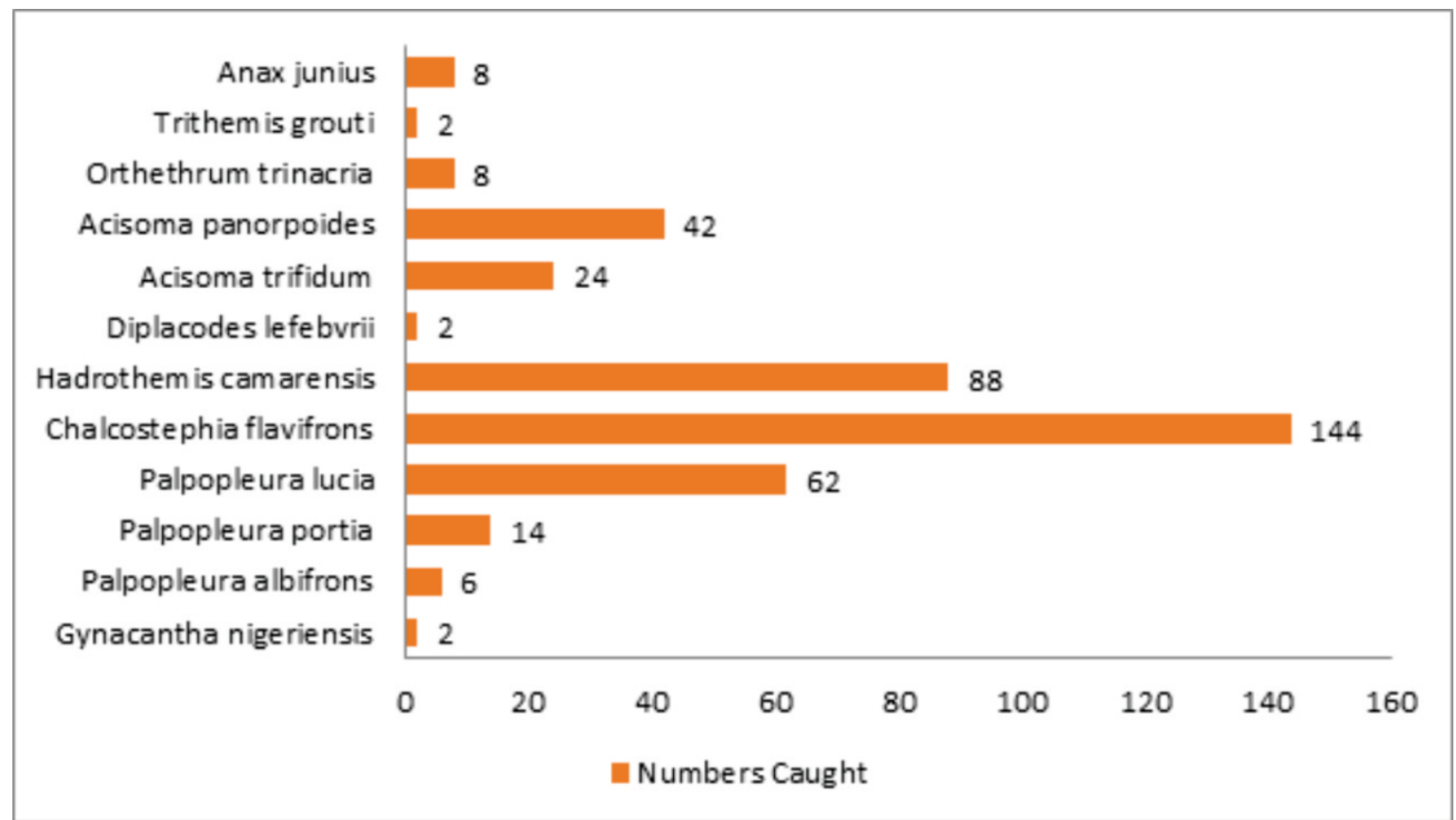

Figure 3: Percentage composition of individuals caught in site 1

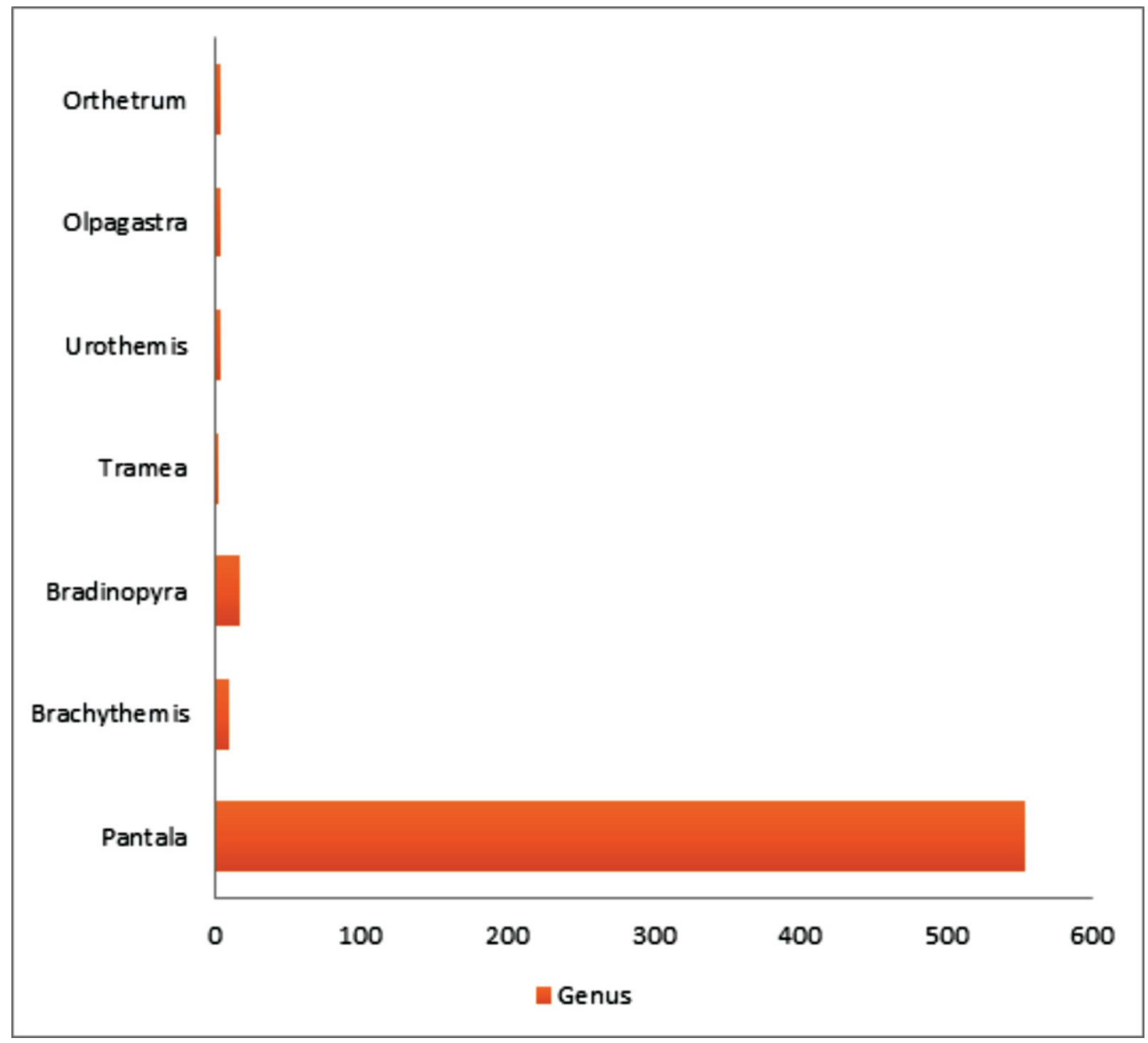

Figure 4: Percentage composition of genera caught in site 2 
Table 2: Diversity indices of odonates collected at the study site

\begin{tabular}{lll}
\hline & Site 1 & Site 2 \\
\hline Taxa_s & 12 & 8 \\
Individuals & 402 & 600 \\
Dominance D & 0.217 & 0.857 \\
Shannon H & 1.808 & 0.391 \\
Simpson_1-D & 0.783 & 0.143 \\
Evenness_e^H/S & 0.508 & 0.185 \\
Menhinick & 0.5985 & 0.3266 \\
Margalef & 1.834 & 1.094 \\
Equitability J & 0.727 & 0.188 \\
Fisher alpha & 2.327 & 1.304 \\
Berger-Parker & 0.358 & 0.925 \\
NB: Site 1 is Fish pond at Ikorodu & \\
\hline
\end{tabular}

Site 2 is Agricultural farm at Ipaja, lagos

Table 3: Odonata community structure similarity test using Sorensen's Quotient in the two study sites

\begin{tabular}{lll}
\hline Paired study sites & Sorensen's Quotient Value & Similarity Status \\
Ikorodu/Ipaja & 0 & Strongly dissimilar \\
\hline
\end{tabular}

\section{Discussion}

The fish ponds and farmland are homes to a diverse range of dragonfly species under the family of Libellulidae. Chalcostephia flavifrons and Pantala flavescens found in Site 1 and Site 2 respectively are ubiquitous and are pioneers of temporary or degraded landscape (Dijkstra and Clausnitzer, 2005). The ponds and farmlands provide the needed environment for the growth and survival of many Afrotropical species of Anisoptera. The environment is conducive and its large population of dragonflies show the environment has a negligible level of pollution however there is constant disturbance in the area although the presence of the fish in the ponds continues to draw the Anisopterans to the area. The tall grasses at the study site 2 provide the right roosting spots for the adult and for the low flying adults, the undergrowth and shrub provide a perching spot. There are also fragmented openings within these sites which serve as mating rendezvous for mature adults, especially at open water bodies such as the ponds. According to Corbet (1999), odonates display two behavioural characteristics which is a function of the habitat selection of the species (eurytopic and stenotopic). Thedominance of the family Libellulidaeis in agreement with studies conducted by Vick, 1999; Clausitzer and Dijkstra, 2011, Adu et al., 2013, 2015, 2016; Kemabonta et al, 2016) It is believed to be the largest Odonata fauna on earth (Clausitzer and Dijkstra, 2005).

Based on the recorded values, the absence and dominance of some species in both study sites accounts for the dissimilarity in the Odonata community structures of the sites and in terms of occurrence and disturbance, it can be speculated that the habitats are disturbed. Disturbance in this context ranges from cutting of vegetation (Site 2) to construction work done around the area (Site 1) and this was a regular occurrence throughout the sampling period and this led to the large migration of the dragonflies as they are known to be sensitive to pollution and anthropogenic activities(Clausnitzer, 2003).Aquatic habitats are normally spatio-temporally restricted, often located within predominantly rural landscapes, and are thereby susceptible to farmland water management practices, which may create additional pressure on water resources. (Mario, 2012).

In agreement with Shannon (1948) in Mandaville (2002), biodiversity indices such as Shannon-Weiner index values revealed that site 2 (Ipaja) having index values below 1.0 was ecologically polluted and degraded and site 1 (Ikorodu) having index values above 1.0 but below 3.0 was a relatively less polluted and degraded area accounting for the paucity in diversity of the odonates.

\section{Conclusion}

Species of dragonflies found in the two sites were completely dissimilar. The slight increase in diversity of site 1 from site 2 can be accounted for by the level of anthropogenic activities present in the two sites. However, both sites are under constant disturbance due to deforestation, commercial and industrial activities. Should anthropogenic activities occurring in neighboring areas lead to the encroachment of the fish ponds 
and the farmland, this would jeopardize the species diversity and overall population of dragonflies and other life at both sites. Hence, there is a need to control all human activities in the area and also maintain the integrity of the fish pond and the farmland in a pollution-free state so as to preserve the diversity of dragonflies as well as the overall population and species diversity of the various organisms that make up the ecosystem of the sites.

\section{References}

Adu, B. W. \&Ogbogu, S. S. (2013). Diversity and community structure of dragonflies and damselflies (Insecta: Odonata) in Aponmu Forest, Southwestern. International Journal of Agriculture and Forestry.3 (6): 231 -239.

Adu, W., Kemabonta, K. A. \&Ogbogu, S. S. (2016). Composition and abundance of Odonates at Alatori stream South-West, Nigeria. UNILAG Journal of Medicine, Science and Technology.4: 96-110.

Adu, W., Ogbogu, S. S. \& Kemabonta, K. A. (2015). Dragonflies and damselflies (Insecta: Odonata) as tools for habitat quality assessment and monitoring. FUTA Journal of Research in Sciences.11 (1): 3645.

Bernard, R. \&Daraz, B. (2018).New records of dragonflies (Odonata) in Zambia.African Invertebrates.52 (9): 165-193.

Berquier, C., Orsini, A., Ferrat, L., \& Andrei-Ruiz, M. C. (2016). "Odonata Community Index-Corsica" (OCIC): A new biological index based on adult odonate populations for assessment of the ecological status of watercourses in Corsica. Ecological Indicators. 66: 163-172.

Clausnitzer, V. (2003). Dragonfly communities in coastal habitats of Kenya: indication of biotope quality and the need of conservation $\mathrm{measures}$. Biodiversity and Conservation.12:333-356.

Clausnitzer, V. and Dijkstra K. D. B., (2011) The dragonflies (Odonata) of Ethiopia, with notes on the status of endemic taxa and the description of a new species. Entomologische Zeitschrift 115: 117-13

Clausnitzer, V., Simaika, J. P., Samways, M. J., and Daniel, B. A. (2017).Dragonflies as flagships for sustainable use of water resources in environmental education. Applied Environmental Education \& Communication, 16(3): 196-209.

Collins, C. M., Bonds, J. A. S., Quinlan, M. M.and Mumford, J. D. (2018).Effects of the removal or reduction in density of the malaria mosquito, Anopheles gambiae, on interacting predators and competitors in local ecosystems. Medical and veterinary entomology. $15 \mathrm{pp}$
Corbet, P. S. (1999). Dragonflies: Behaviour Ecology of Odonata. Cornell University Press, New York. 845pp.

Dijkstra, K. D., and Clausnitzer, V. (2014).The dragonflies and damselflies of eastern Africa: handbook for all Odonata from Sudan to Zimbabwe. Royal Museum for Central Africa.

Dijkstra, K. D. B., and Vick, G. S. (2004).Critical species of Odonata in western Africa. International Journal of Odonatology, 7(2), 229-238.

Duong, M. T. (2017). Response of adult dragonflies to prey of different size and colour in the context of anti-predator defences (Doctoral dissertation, Carleton University). 62pp.

Kalkman, V. J., Clausnitzer, V., Dijkstra, K. B., Albert, G. O., Paulson, D. R. and Tol, J. V. (2008). Global diversity of Dragonflies ( $\mathrm{O} \mathrm{d}$ o $\mathrm{n}$ a t a ) i n freshwater.Hydrobiologia.595:351-363.

Kemabonta, K. A., Adu, B. W and Ohadiwe, A. C (2016).Impact of human disturbance on the abundance, diversity and distribution of Odonata in the University of Lagos. Applied Tropical Agriculture. 21 (3): 143-150.

Mandaville, S. M. (2002). Benthic macroinvertebrates in freshwaters: Taxa tolerance values, metrics, and protocols (pp. 21-38). Nova Scotia: Soil \& Water Conservation Society of Metro Halifax.

Mario, V. B. (2012).Associations of dragonflies (Odonata) to habitat variables within the Maltese Islands: A spatio-temporal approach. Journal of Insect Science. 12(1): 87

Sahlen, G., Bernard, R., Rivera, A. C., Ketelaar, R. and Suhling, F. (2004). Critical species of Odonata in Europe. In Clausnitzer, V. and Jodicke, R. (eds). Guardians of the Watershed.Global Status of Dragonflies: Critical Species, Threat and Conservation. International Journal of Odonatology.7: 385-398.

Sarmistha, J., Priti, R., Tapan, P., Dutta, K. and Tanmay, B. (2009). Diversity and community structure of aquatic insects in a pond in Midnapore town, West Bengal, India. Journal of Environmental Biology.30 (2): 283-287.

Schneider, W. and Samraoui, B. (2015). The status and distribution of dragonflies and damselflies (Odonata) in the Arabian Peninsula. Chapter: 5, Publisher: IUCN.pp.39-55

Shannon, C. E. (1948). A mathematical theory of communication. The Bell System Technical Journal.27: 379-423.

Vick, G. S. (1999). A checklist of the Odonata of the South-West province of Cameroon, with the description of Phyllogomphuscorbefae spec. nov. (Anisoptera: Gomphidae). 